\title{
Phytoplankton response to winter warming modified by large-bodied zooplankton: an experimental microcosm study
}

\author{
$\mathrm{Hu} \mathrm{HE},{ }^{1,2}$ Xiaolong ZHU, ${ }^{3}$ Xiaolan SONG, ${ }^{4}$ Erik JEPPESEN, ${ }^{5,6}$ Zhengwen LIU ${ }^{1,6,7^{*}}$ \\ ${ }^{1}$ State Key Laboratory of Lake Science and Environment, Nanjing Institute of Geography and Limnology, Chinese Academy of Sci- \\ ences, 210008 Nanjing, China; ${ }^{2}$ University of Chinese Academy of Sciences, 100049 Beijing, China; ${ }^{3}$ School of Environmental and \\ Civil Engineering, Jiangnan University, 214122 Wuxi, China; ${ }^{4}$ Jiangyin Environmental Monitoring Station, 214431 Jiangyin, China; \\ ${ }^{5}$ Department of Bioscience, Aarhus University, 8000 Aarhus C, Denmark; ${ }^{6}$ Sino-Danish Centre for Education and Research, 100049 \\ Beijing, China; ${ }^{7}$ Department of Ecology and Institute of Hydrobiology, Jinan University, 510632 Guangzhou, China \\ *Corresponding author: zliu@niglas.ac.cn
}

\begin{abstract}
While several field investigations have demonstrated significant effects of cool season (winter or spring) warming on phytoplankton development, the role played by large-bodied zooplankton grazers for the responses of phytoplankton to winter warming is ambiguous. We conducted an outdoor experiment to compare the effect of winter warming (heating by $3^{\circ} \mathrm{C}$ ) in combination with presence and absence of Daphnia grazing (D. similis) on phytoplankton standing crops and community structure under eutrophic conditions. When Daphnia were absent, warming was associated with significant increases in phytoplankton biomass and cyanobacterial dominance. In contrast, when Daphnia were present, warming effects on phytoplankton dynamics were offset by warming-enhanced grazing, resulting in no significant change in biomass or taxonomic dominance. These results emphasize that large-bodied zooplankton like Daphnia spp. may play an important role in modulating the interactions between climate warming and phytoplankton dynamics in nutrient rich lake ecosystems.
\end{abstract}

Key words: Winter warming, Daphnia, cyanobacterial dominance, microcosms.

Received: July 2015. Accepted: March 2015.

\section{INTRODUCTION}

Earth is steadily warming. The globally averaged surface temperature has experienced a warming of $0.85^{\circ} \mathrm{C}$ over the period 1880 to 2012 (IPCC, 2014). In the subtropical part of China, the past half century (1951-2001) has also seen pronounced warming (Hu et al., 2003). The strongest temperature increases are often observed in winter and spring (Sha et al., 2002; Carvalho and Kirika, 2003), perhaps induced by large-scale meteorological phenomena such as the North Atlantic Oscillation (NAO) or the Arctic Oscillation (AO) (Gong et al., 2004; Blenckner et al., 2007).

Warming during cold seasons has profound ecological effects, not least on lake phytoplankton dynamics (Peeters et al., 2007). Diatom blooms are a dominant seasonal feature of phytoplankton communities in temperate or cold regions, and numerous studies have indicated that the timing, magnitude and composition of such events is influenced by winter/spring warming (Peeters et al., 2007; Sommer and Lewandowska 2011). From the perspective of lake management, climate warming is often expected to result in increased phytoplankton biomass, especially in productive lakes. An 18-year (1975-1992) investigation undertaken in Germany's hypereutrophic Heiligensee Lake found that winter densities of algae were signifi- cantly elevated in warmer years (Adrian et al., 1995). A comparative study suggested that the winter phytoplankton yield (chlorophyll $a$ :total phosphorus ratio) in shallow Danish lakes, which routinely experience relatively warm winters, was four times higher than in shallow Canadian lakes exposed to cold winters (Jackson et al., 2007), the underlying mechanisms being a much higher top-down control on phytoplankton by zooplankton grazing caused by fish mortality under ice in the winter cold Canadian lakes (Jackson et al., 2007).

It is well established that elevated temperatures may simultaneously accelerate the physiological rates of both producers and grazers. Large-bodied zooplankton, e.g., Daphnia spp., are important filter feeders in shallow lakes. In some fish-free lakes, such as those at higher altitudes or where fish are artificially removed, Daphnia can be very abundant and exerting a continuously high grazing pressure on phytoplankton (Jeppesen et al., 2012). In such lakes, the positive effect of warming on phytoplankton growth may be compensated by enhanced grazing during the cooler seasons (Sommer and Lewandowska, 2011). Previous longterm field investigations have also reported phytoplankton biomass reductions during warmer winters in lakes with abundant Daphnia, such as Lake Constance in Germany and Loch Leven in Great Britain (Straile, 2000; Carvalho 
and Kirika, 2003). However, definite evidence for the interactive effect of large-bodied zooplankton and warming on phytoplankton dynamics remains scarce.

We conducted an outdoor microcosm experiment to mimic the effects of winter warming on phytoplankton dynamics in contrasting lake ecosystems, one with abundant Daphnia and one without. We hypothesized that warming would significantly promote the growth of phytoplankton when Daphnia is absent. However, at high Daphnia abundance, warming-enhanced grazing was hypothesized to potentially dampen the warming effect on phytoplankton dynamics.

\section{METHODS}

\section{Experimental design}

The outdoor microcosm experiment was conducted from 22 November to 7 December 2013 at Taihu Laboratory for Lake Ecosystem Research (TLLER), located in Meiliang Bay, on the northern edge of Lake Taihu. The microcosms were 16 transparent carboys (30-cm height; 11$\mathrm{cm}$ upper diameter; and $17-\mathrm{cm}$ bottom diameter). Prior to the experiment, all carboys were cleaned with $0.01 \mathrm{~N} \mathrm{HCl}$ and rinsed repeatedly with lake water. Water samples containing the winter phytoplankton assemblages naturally present in Lake Taihu were collected $0.3 \mathrm{~m}$ below the surface in Meiliang Bay. The water samples were screened (112- $\mu \mathrm{m}$ mesh size) to remove crustacean zooplankton and inorganic particles and then stored in a 140-L polyethylene bucket. After stirring to ensure homogeneity, 6-L mixed water samples from the bucket were distributed into each carboy. The carboys were unsealed during the whole experimental period, and placed randomly in one of two plastic tanks (67 cm long x $52 \mathrm{~cm}$ wide x $30 \mathrm{~cm}$ high), which were filled with lake water and hung in a concrete pond (7 $\mathrm{m}$ long $\mathrm{x} 6 \mathrm{~m}$ wide $\mathrm{x} 2 \mathrm{~m}$ deep).

A two-way factorial experiment was carried out with two temperature levels (unheated and heated) and two zooplankton levels (Daphnia present/absent). Each treatment had four replicates, making up a total of 16 experimental units. Different climate scenarios were established separately in each of the two tanks. In one tank, the water temperature was held at the ambient level, while the other tank was heated to simulate future climate warming using a customized intelligent temperature-control device with two 200 -W heating rods to raise the temperature by $+3^{\circ} \mathrm{C}$ relative to the control. The heating system had a gross precision of $\pm 0.5^{\circ} \mathrm{C}$. Real time temperature in both heated and unheated tanks was measured/logged automatically every minute.

The zooplankton used in the experiment was Daphnia similis, a common species in Lake Taihu and other shallow lakes, with an average body length of $1.2 \mathrm{~mm}( \pm 0.2$ $\mathrm{mm})$. D. similis were added to the zooplankton treatments at a density of 5 ind $\mathrm{L}^{-1}$, which is comparable to that recorded in Lake Taihu during winter-spring periods (Chen et al., 2011). The zooplankton were collected from the concrete pond using a plankton net $(112-\mu \mathrm{m}$ mesh size) and cultivated in situ using filtered water for three days prior to the commencing of the experiment. After adding zooplankton to the assigned microcosms, heating was conducted uninterrupted until the end of the experiment. During the experimental period, nutrients (5 $\mu \mathrm{g} \mathrm{P}$ $\mathrm{L}^{-1} \mathrm{~d}^{-1} ; 130 \mu \mathrm{g} \mathrm{N} \mathrm{L}^{-1} \mathrm{~d}^{-1}$ ) were added to each microcosm daily to simulate external loading in the lake. Phosphorus and nitrogen were added separately as aqueous solutions of potassium dihydrogen phosphate $\left(\mathrm{KH}_{2} \mathrm{PO}_{4}\right)$ and potassium nitrate $\left(\mathrm{KNO}_{3}\right)$, the dominant inorganic nutrient forms in Lake Taihu. In our study, the final concentration of $\mathrm{N}$ was $3.09 \mathrm{mg} \mathrm{N} \mathrm{L}^{-1}$, and the final concentration of $\mathrm{P}$ was $0.12 \mathrm{mg} \mathrm{P} \mathrm{L}^{-1}$. These nutrient levels are commonly found in the eutrophic areas of Lake Taihu (Xu et al., 2010).

\section{Sampling procedure and data acquisition}

Water chemicals and phytoplankton were sampled at the beginning (Day 0) and at the end (Day 16) of the experiment. The experiment was stopped when Daphnia reached the highest levels found in winter-spring period in Lake Taihu (Chen et al., 2011). Before sampling, all carboys were shaken mechanically to ensure that the water was homogenously mixed. A small $(50 \mathrm{~mL})$ integrated sample was then collected from each unit.

The water samples were fixed immediately with 0.5 $\mathrm{mL}$ Lugol's iodine solution to enable phytoplankton species identification and cell enumeration. A $25-\mathrm{mL}$ subsample from each of integrated $50 \mathrm{~mL}$ sample was settled in a plankton cylinder (Uwitec Corporation, Mondsee, Austria) for $48 \mathrm{~h}$, and then concentrated in a 3-mL plankton-counting chamber (Uwitec Corporation). The organisms were counted using an inverted microscope (Nikon ECLIPSE TS-100) at 100-400× magnification (40-50 fields). Taxa were identified to at least genus level, the dominant forms being identified to species following $\mathrm{Hu}$ (1980) and using, as far as possible, recent taxonomic revisions (Guiry and Guiry, 2014). Biomasses of common phytoplankton taxa were calculated based on cell size measurements of at least 30 cells of each taxon (when possible) and using formulae for geometric shapes approximating cell forms (Zhang and Huang, 1991). At least 1000 cells of the dominant taxon were counted per sample.

Zooplankton was counted at the end of experiment. After phytoplankton sampling, all the remaining water from each microcosm containing Daphnia was collected and filtered through a plankton net (112- $\mu \mathrm{m}$ mesh size). The net contents were preserved with $4 \%$ formaldehyde and $D$. similis were then counted at $40 \times$ magnification. The variations in phytoplankton biomass between the four 
treatments were analysed by multiple analysis of variance (MANOVA) $(\mathrm{P}<0.05)$. In the event of significant interaction terms, a Bonferroni procedure was performed to determine where the differences occurred, using zooplankton as a categorical factor and temperature as a quantitative factor. Daphnia densities in two temperature treatments were compared using Student's $t$-test at 5\% level. Prior to analysis, the data were transformed to meet the requirements of normal distribution and homogeneity of variance. All the comparisons in this study were performed with the statistical package SPSS, version 16.0 (IBM Corporation, Somers, NY, USA).

\section{RESULTS}

During the first four days of the experiment, temperatures fluctuated between 11.6 and $13.5^{\circ} \mathrm{C}$ (Fig. 1), followed by a decline to approximately $9^{\circ} \mathrm{C}$ after day 8 . The temperature in the heated microcosms was $3.05^{\circ} \mathrm{C}$ higher than in the unheated tanks.

At the beginning of the experiment, total phytoplankton biomass was $14.4 \mathrm{mg} \mathrm{L}^{-1}$ in average. The phytoplankton community comprised mainly Microcystis $(34.0 \%$ in total algal biomass), Fragilaria (17.28\%), Cryptomonas (8.9\%), Euglena (8.3\%), and Pseudoanabaena (8.2\%). MANOVA did not reveal any significant differences between the four treatment groups, indicating homogeneity prior to the addition of zooplankton and experimental warming. Total phytoplankton biomass responded significantly to both warming and Daphnia addition, and the interaction between the two factors was also significant (Fig. 2; Tab. 1). In treatments without Daphnia, the growth of phytoplankton was significantly enhanced by elevated temperature (Fig. 2), average algal biomass being 1.5 times greater in the heated microcosms than in the unheated microcosms by the end of the experiment. However, in the microcosms with Daphnia, the temperature effect on phytoplankton biomass was not significant (Fig. 2). At the end of experiment, three major phytoplankton species were recorded in the water samples across all treatments, the cyanobacterium Pseudoanabaena limnetica (Lemmermann) Komárek 1974 and two diatoms, Ulnaria ulna (Nitzsch) P.Compère 2001 and Cyclotella meneghiniana Kützing 1844, hereafter referred to by genus only (Fig. 2). These three taxa collectively comprised $>80 \%$ of the total assemblage biomass.

Significant effects of temperature, Daphnia addition and their interaction were observed on Pseudoanabaena biomass (Fig. 2; Tab. 1). In the microcosms without Daphnia, the growth of Pseudoanabaena was significantly enhanced by heating, with the average biomass being 1.8 times higher in the heated than in the unheated microcosms (Fig. 2), while no differences were found when Daphnia were present (Fig. 2). Temperature elevation and addition of Daphnia both had a negative effect on the biomass of Cyclotella (Fig. 2; Tab. 1), whereas the biomass of Ulnaria was significantly affected only by temperature elevation (Fig. 2; Tab. 1). MANOVA indicated that the interaction effects of temperature and Daphnia addition were insignificant for both diatom species

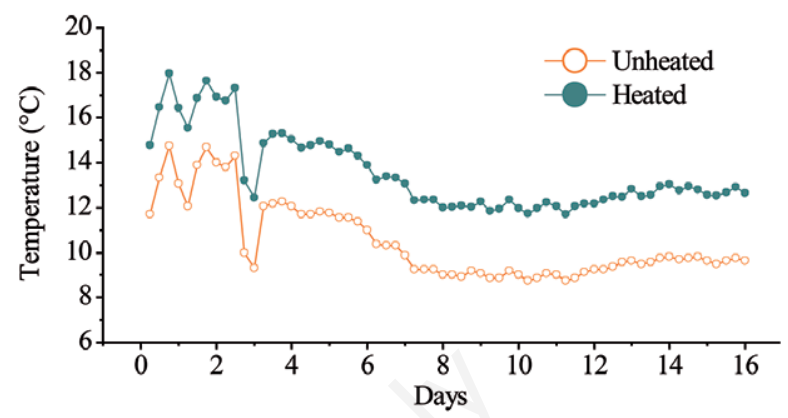

Fig. 1. Time course of temperature development $\left({ }^{\circ} \mathrm{C}\right)$ in both experimental climate scenarios. Unheated, surface water temperature of ponds; heated, $+3^{\circ} \mathrm{C}$ increase above unheated temperature.

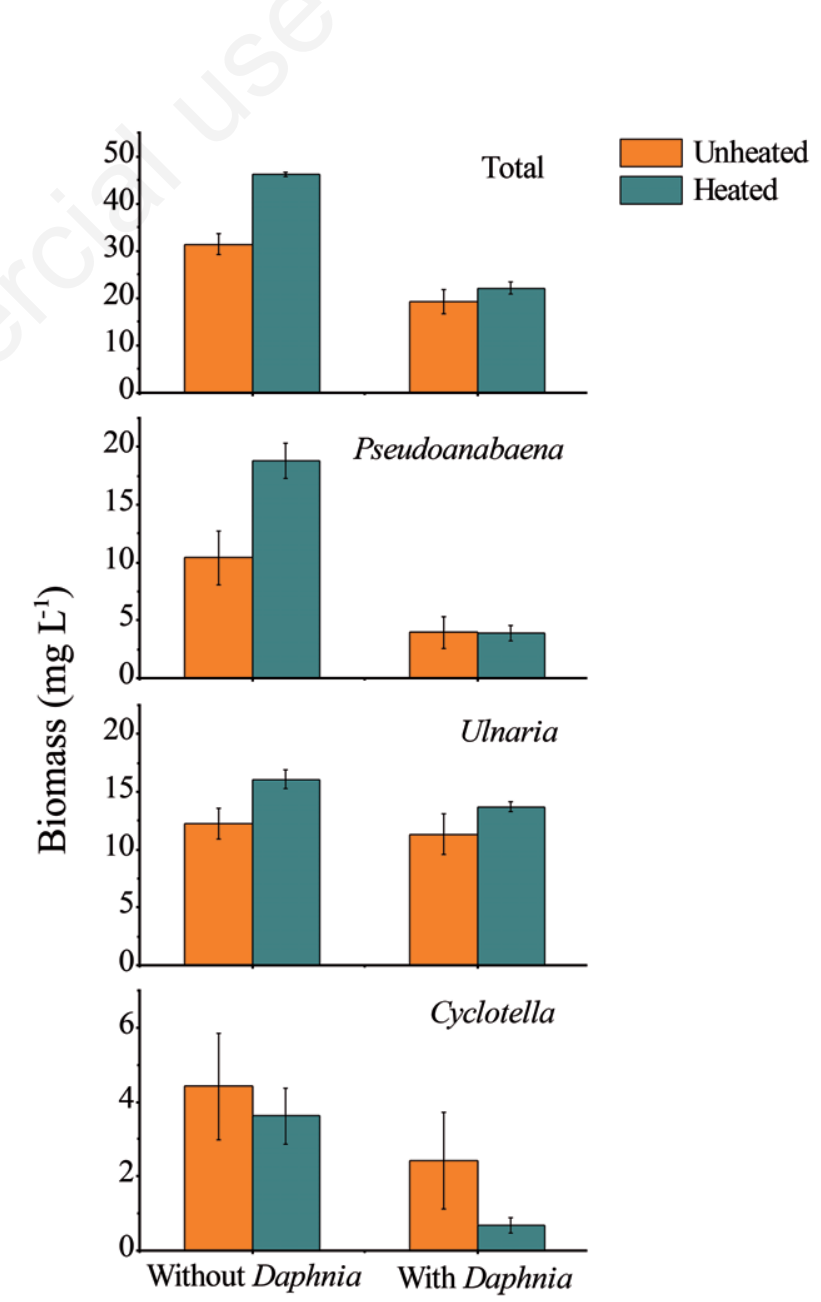

Fig. 2. Comparison of total phytoplankton and major taxon biomass between four treatments. Unheated, surface water temperature of ponds; heated, $+3^{\circ} \mathrm{C}$ increase above unheated temperature. The bars show standard deviations. 
(Tab. 1). In treatments with Daphnia, temperature had a significant effect on Daphnia densities $(\mathrm{P}<0.001)$, which were almost doubled in the heated microcosms relative to the unheated controls (Fig. 3).

\section{DISCUSSION}

As hypothesized, we found a significant interactive effect of climate warming and Daphnia grazing on phytoplankton dynamics (Tab. 1). In the absence of Daphnia grazing, biomasses of phytoplankton responded positively to a temperature increase (Fig. 2; Tab. 1), which was largely attributed to the fast-growing cyanobacteria (Pseudanabaena) (Fig. 2). Previous microcosm studies have also revealed that cyanobacteria are often more sensitive to temperature elevation than other phytoplankton groups (De Senerpont Domis et al., 2007). Moreover, field investigations in eutrophic Heiligensee and Lake Taihu, dominated by small-sized zooplankton, also found significant promotion of cyanobacteria in warm winters (Adrian et al., 1995; Duan et al., 2014). Warming also promoted the growth of Ulnaria but reduced Cyclotella biomass (Fig. 2; Tab. 1), a disparity that may be attributed to the competitive advantage of epiphytic taxa (Ulnaria) in small scale experiments like ours. In the microcosms with Daphnia, winter warming significantly enhanced the growth of zooplankton (Fig. 3) and consequently caused an elevated grazing on phytoplankton, which fully counteracting the warming effects on phytoplankton growth (Fig. 2). In field studies such negative effects of largebodied zooplankton on phytoplankton biomass have also been seen in warm winters, for example in Lake Constance (Straile, 2000) and Loch Leven (Carvalho and Kirika, 2003). Moreover, our results are also in line with experimental studies in Danish lakes run with and without fish predation (Sørensen et al., 2011). The warming-en- hanced grazing by Daphnia also reduced the density of Cyclotella but had no obvious effect on Ulnaria (Fig. 2; Tab. 1), which may be attributed to the large cell length of Ulnaria. Some studies have suggested that grazing by Daphnia might be inhibited by filamentous algae as zooplankton have difficulty in handling the long filaments (Infante and Abella, 1985). However, our study recorded a clear growth reduction of filamentous Pseuanabena by D. similis, concurring with the results of biomanipulation studies where fish removal resulted in higher Daphnia biomass and a marked decline in cyanobacteria (Jeppesen et al., 2012).

Being of small scale, short duration and using only one zooplankton species, our experiment obviously have some limitations and must be interpreted with caution

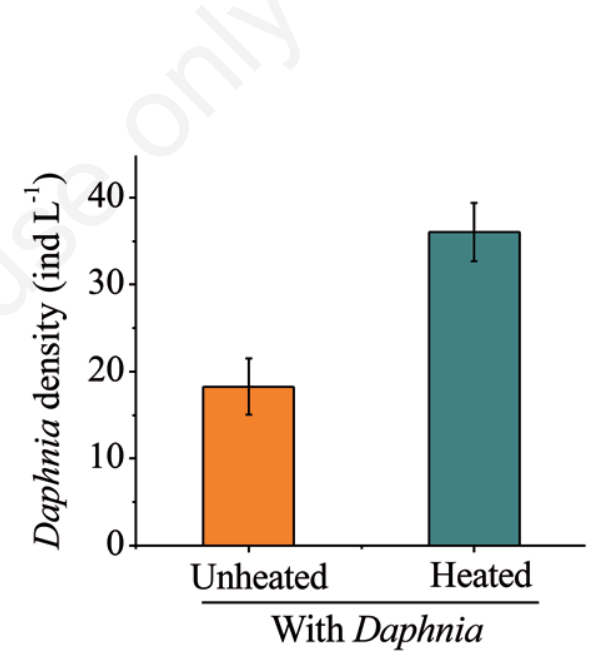

Fig. 3. Daphnia density in both treatments at the end of experiment. Unheated, surface water temperature of ponds; heated, $+3^{\circ} \mathrm{C}$ increase above unheated temperature. The bars show standard deviations.

Tab. 1. Multiple Analysis of Variance (MANOVA) results for biomass of total phytoplankton and for major phytoplankton species.

\begin{tabular}{|c|c|c|c|c|c|}
\hline Variables & Effect & DF1 & DF2 & $F$ value & $\operatorname{Pr}>F$ \\
\hline Pseudanabaena & $\begin{array}{l}\text { Warming } \\
\text { Daphnia } \\
\text { Warming } \times \text { Daphnia }\end{array}$ & $\begin{array}{l}1 \\
1 \\
1\end{array}$ & $\begin{array}{l}12 \\
12 \\
12\end{array}$ & $\begin{array}{c}20.92 \\
132.70 \\
25.88\end{array}$ & $\begin{array}{c}0.002 \\
<0.001 \\
0.001\end{array}$ \\
\hline \multirow[t]{3}{*}{ Cyclotella } & Warming & 1 & 12 & 26.09 & 0.001 \\
\hline & Daphnia & 1 & 12 & 39.13 & $<0.001$ \\
\hline & Warming $\times$ Daphnia & 1 & 12 & 0.43 & 0.532 \\
\hline Ulnaria & $\begin{array}{l}\text { Warming } \\
\text { Daphnia } \\
\text { Warming } \times \text { Daphnia }\end{array}$ & $\begin{array}{l}1 \\
1 \\
1\end{array}$ & $\begin{array}{l}12 \\
12 \\
12\end{array}$ & $\begin{array}{l}7.32 \\
1.08 \\
2.68\end{array}$ & $\begin{array}{l}0.019 \\
0.318 \\
0.128\end{array}$ \\
\hline \multirow[t]{3}{*}{ Total } & Warming & 1 & 12 & 95.50 & 0.001 \\
\hline & Daphnia & 1 & 12 & 398.49 & $<0.001$ \\
\hline & Warming $\times$ Daphnia & 1 & 12 & 43.92 & $<0.001$ \\
\hline
\end{tabular}

DF1, DF2, degree of freedom of numerator and denominator, respectively. 
(Stewart et al., 2013). However, even though the interactions might be stronger in such a small scale experiment than might be found in natural lakes, e.g., Lake Taihu, the direction of change is supported by observation both from larger scale experiments (Sørensen et al., 2011) and field data (Duan et al., 2014).

\section{CONCLUSIONS}

Our study showed that at identical nutrient loading, warming in regimes without Daphnia significantly boosted the growth of cyanobacteria (Fig. 2; Tab. 1). Our study, however, also revealed that when Daphnia are abundant, the effect of warming is to some extent moderated by their grazing. The results, therefore, emphasize that large-bodied zooplankton like Daphnia spp. will play an important role in modulating the interactions between climate warming and phytoplankton dynamics in lake ecosystems if not controlled by predation.

\section{ACKNOWLEDGMENTS}

This study was supported by the National Basic Research Program of China (No. 2012CB956100), the National Science Foundation of China (No. U1033602 and 41073057), the Key Project of the 135 program of Nanjing Institute of Geography and Limnology, the CAS/SAFEA International Partnership Program for Creative Research Teams. We also acknowledge funding from the MARS project (Managing Aquatic ecosystems and water Resources under multiple Stress) under the $7^{\text {th }}$ EU Framework Programme, Theme 6 (Environment including Climate Change, Contract No: 603378, http://www.mars-project.eu), CLEAR (a Villum Kann Rasmussen Centre of Excellence project), CRES and CIRCE.

\section{REFERENCES}

Adrian R, Deneke R, Mischke U, Stellmacher R, Lederer P, 1995. A long-term study of the Heiligensee (1975-1992). Evidence for effects of climatic change on the dynamics of eutrophied lake ecosystems. Arch. Hydrobiol. 133:315-337.

Blenckner T, Adrian R, Livingstone DM, Jennings E, Weyhenmeyer GA, George D, Jankowski T, Järvinen M, Aonghusa CN, Nõges T, 2007. Large-scale climatic signatures in lakes across Europe: a meta $\square$ analysis. Global Change Biol. 13:1314-1326.

Carvalho L, Kirika A, 2003. Changes in shallow lake functioning: response to climate change and nutrient reduction. Hydrobiologia 506-509:789-796.

Chen FZ, Gulati RD, Li J, Liu ZW, 2011. A comparison of the size distribution of the filamentous green alga Ulothrix in Daphnia guts and lake water from Lake Taihu, China. J.
Plankton Res. 33:1274-1283.

De Senerpont Domis LN, Mooij WM, Huisman J, 2007. Climateinduced shifts in an experimental phytoplankton community: a mechanistic approach. Hydrobiologia 584:403-413.

Duan HT, Ma RH, Zhang YL, Loiselle SA, 2014. Are algal blooms occurring later in Lake Taihu? Climate local effects outcompete mitigation prevention. J. Plankton Res. 36:866-871.

Gong D, Wang S, Zhu J, 2004. Arctic Oscillation influence on daily temperature variance in winter over China. Chinese Sci. Bull. 49:637-642.

Guiry MD, Guiry, GM, 2014. Algaebase. World-wide electronic publication. National University of Ireland, Galway.

Hu HJ, Li YY, Wei YX, Zhu HZ, Chen JY, Shi ZX, 1980. [Chinese freshwater algae].[Book in Chinese]. Science and Technology Press, Shanghai.

Hu ZZ, Yang S, Wu R, 2003. Long-term climate variations in China and global warming signals. J. Geophys. Res. 108:4614-4626.

Infante A, Abella SE, 1985. Inhibition of Daphnia by Oscillatoria in Lake Washington. Limnol. Oceanogr. 30:1046-1052.

IPCC, 2014. Climate change 2014: synthesis report. Available from: http://www.ipcc.ch/report/ar5/syr/

Jackson LJ, Lauridsen TL, Søndergaard M, Jeppesen E, 2007. A comparison of shallow Danish and Canadian lakes and implications of climate change. Freshwater Biol. 52:1782-1792.

Jeppesen E, Søndergaard M, Lauridsen TL, Davidson TA, Liu Z, Mazzeo N, Trochine C, Özkan K, Jensen HS, Trolle D, Starling F, Lazzaro X, Johansson LS, Bjerring R, Liboriussen L, Larsen SE, Landkildehus F, Meerhoff M, 2012. Biomanipulation as a restoration tool to combat eutrophication: recent advances and future challenges. Adv. Ecol. Res. 47:411-487.

Peeters F, Straile D, Lorke A, Livingstone DM, 2007. Earlier onset of the spring phytoplankton bloom in lakes of the temperate zone in a warmer climate. Global Change Biol. 13:1898-1909.

Sommer U, Lewandowska A, 2011. Climate change and the phytoplankton spring bloom: warming and overwintering zooplankton have similar effects on phytoplankton. Global Change Biol. 17:154-162.

Sørensen T, Mulderij G, Søndergaard M, Lauridsen TL, Liboriussen L, Brucet S, Jeppesen E, 2011. Winter ecology of shallow lakes: strongest effect of fish on water clarity at high nutrient levels. Hydrobiologia 664:147-162.

Stewart, RI, Dossena M, Bohan DX, Jeppesen E, Kordas RL, Ledger ME, Meerhoff M, Moss B, Mulder C, Shurin JB, 2013. Mesocosm experiments as a tool for ecological climate-change research. Adv. Ecol. Res. 48:171-181.

Straile D, 2000. Meteorological forcing of plankton dynamics in a large and deep continental European lake. Oecologia 122:44-50.

Xu H, Paerl HW, Qin BQ, Zhu GW, Gao G, 2010. Nitrogen and phosphorus inputs control phytoplankton growth in eutrophic Lake Taihu, China. Limnol. Oceanogr. 55:420-432.

Zhang ZS, Huang XF, 1991. [Methods in freshwater plankton study].[Book in Chinese]. Science Press, Beijing. 